\title{
系統保護リレー信頼度解析システムの開発
}

\author{
正員 亀田秀之 (電力中央研究所)
}

\section{Development of Reliability Analysis System for Protective Relays}

\author{
Member Hideyuki Kameda (CRIEPI)
}

It is expected that the introduction of the competition policy would bring us cheaper electricity. The effective use of protective equipment and the rationalization of the maintenance procedure are needed. To realize them, a reliability analysis system for protective relays has been expected. Conventional systems or methods didn't enable us to analyze the annual change of the reliability nor the reliability when maintenance procedure would be changed.

The Reliability Analysis System for protective relays (RASPR) developed satisfies the above requirements and solves the problems. The RASPR consists of two databases and reliability analysis part. The RASPR realizes to analyze the annual change of the reliability in combination with two databases and to analyze the influence on the index of the reliability according to the change of transition parameters. The construction method of an arbitrary transition diagram enables us to analyze the reliability under any maintenance procedure or for any type of protective relays.

This paper describes the features of the RASPR, the construction method of an arbitrary transition diagram, and finally some examples of the reliability analysis. The RASPR is in operation at all electric power companies in Japan.

キーワード：保護リレー，状態遷移図，信頼度，信頼度解析システム，基本ブロック

\section{1. まえがき}

電力自由化が内外で進められており，我が国においても， 部分自由化が導入され，より一層のコストダウンが求められ ている。保護りレーを取り巻く状況でも，より一層の設備の 有効活用, 保守運用の合理化が求められている。こうした背 景から，保護リレーの信頼度の推移を継続的に解析可能で， かつパソコン上で動作するシステムの開発が望まれていた。

保護リレーの信頼度解析については, ニューヨーク大停電 を契機に保護リレーを構成要素ごとの誤不動作率，譔動作率 などにより解析したのが始まりである(1)。それ以後，保護り レーの信賴度解析は，主に電気協同研究会の下で行われてき た(1)-(6)。

信頼度解析の手法として, 保護リレーが系統に導入されて から，廃止されるまでの閒で各状態の滞在率を解析する状態 遷移図を用いる方法は，文献(1),(7)により提案された(状態遷 移図の詳紐については文献(6)参照)。この状態遷移図はそれ ぞれ電気機械型，アナログ静止型など，機種を限定したもの であった。ディジタル型については文献(5)(8)で解析され， その後第二世代ディジタル型の出見による自動監視機能の 充実, 自動監視対象範囲の拡大，故障発見までの時閒の短縮， などにより，改良が行われた(6)。しかしながら，保守・運用 方法が変化した場合には別途, 状態遷移図を構筑しプログラ ムを書き換える必要があった。

諸外国に目を向けると，CIGRE SC34(保護) の報告(9)があ るが，保守・運用の状況や自動監視のあり方，さらに保護り レーの不要動作件数や送電線の事故率などの調查が主であ
る。したがって，本論文での解析手法とは異なり，また継続 的に調查などは実施されていないと考えられる。

本論文では，信賴度解析に必要な設備データと故障データ をデータベースにより一元管理しこれらデータに基づいて 信賴度の推移を継続して解析可能な保護りレ一信頼度解析 システム(RASPR)について述べる。さらに，保守運用方法が 変化した場合にもプログラムを変更することなく任意の状 態遷移図の構築が可能な手法を提案する。最後に解析例とし て，平成9年度の設備および故障デー夕を用いた信頼度解析 結果, さらに定期点㭘周期を変化した場合の遷移時間率の変 化に対する信頼度指標への影響解析の例を示す。

\section{2. 保護リレー信頼度解析システム}

$<2.1>$ 開発したシステムの構成＼cjkstart開発した保護リレー信 賴度解析システム(RASPR)の構成を図 1 に示守。RASPRは, 保護リレ一設備に関する情報を格納する設備データ管理シ ステムと保護りレーに発生した故障に関する情報を格納す る故障データ管理システムという2つのデータベース, さら に3章で述べる状態㟟移図構築手法に基づく信頼度分析部加 ら構成される。

設備データ管理システムあるいは故障デー夕管理システ ムでは，リレーの分析に必要な諸条件（リレー方式や機種な ど）を設定し、メニュー画面から所望の集計を行う機能を持 つ。集計された結果はEXCELあるいは text形式で外部ファ イルに出力される。信頼度分析部では，信頼度解析を行うリ レーの諸条件を設定すると累積稼動時閒の計算, 故障程度別 に分類された故障発生件数が集計され，故障率が計算される。 
次に，考慮する状態遷移図が構成される(図3参照)。これに vなどの遷移パラメータ(<3.2>参照)を設定することにより， 所望のリレー方式に関する信賴度計算が行われる。

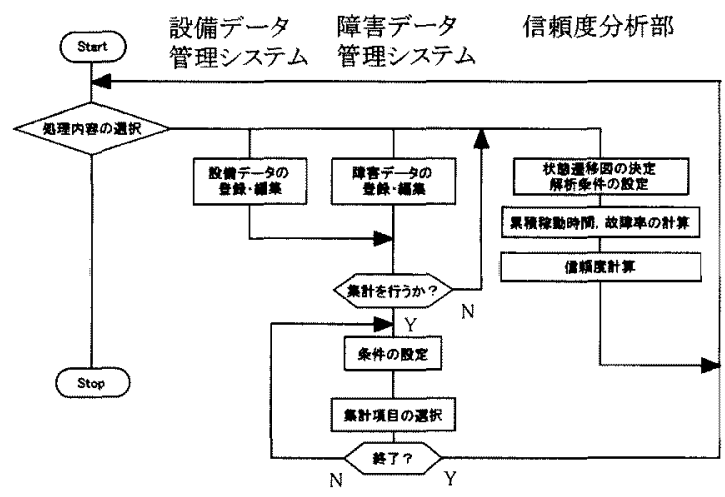

图 1 保譪リレー信頼度解析システムの榙成 Fig. 1 Configuration of RASPR

$<2.2>$ 収集

（1）収集データの考え方 設備データ㧍よび故障データの
収集に当たっては下記の考え方に基づき項目を決定した。

(1) 各社で適用されている送電線，母線，変圧器保護を すべて包含する

(2) Wずれの機種(ディジタル，アナログ静止，電気機械) であっても考慮可能とする

(3) 各社で保有しているデータを最大限収集する

(4) 全国大での集計のため，用語などを統一化し，統計 処理を可能とする

このような考え方のもとに，整理・分類した収集するデー 夕の項目とその内容を表 1 に示す。これらのデータは毎年 1 回収集され，データベースに格納される。

(2)データベース構築に際しての留意事項次に, データ ベース構築に際して考慮した事項を述べる。

(1) 入力項目が多いため，入力力法を容易にする

(2) 俱ったデータの入力を極力防止する

(3) 入力漏れを防止する

(4) データの検索を容易にする

(5) 独自のデータ分類をある程度可能とする

(6) パスワードを設けデータの保護を実施する

表1 収集されるデータの概要

Tab. 1 Outline of Data Acquired in RASPR

\begin{tabular}{|c|c|c|}
\hline & 項 目 & 内 \\
\hline \multirow{17}{*}{$\begin{array}{l}\text { 設 } \\
\text { 備 } \\
\text { デ } \\
1 \\
\text { タ }\end{array}$} & 電力会社名 & 初期立ち上げ時に選択 \\
\hline & 支店名 & 任意に20項目を登録，以後登録した項目がら選択 \\
\hline & 電気庎名 & 全角10文字 \\
\hline & 電厓階級 & $1000,500,275,220,187,154,132,110,77,66,44,33,22,11,6.6[\mathrm{kV}]$ 力ら選択。但し，集計は66kV以上 \\
\hline & 接地方式 & 管圧階級に応じて決定(デフォルトは187以上が直接，154以下が抵抗接地) \\
\hline & 設備名 & 全角16文字 \\
\hline & 区分 & 送電線，変圧器，母線保護，その他から選挆 \\
\hline & リレー方式 & 区分に忘して変化。送電線保煐13方式，母線保護8方式，変圧器保護5方式から選択 \\
\hline & 機種 & ディジタル，アナログ静止，電気機械から選択 \\
\hline & $x-\phi$ & 要7社，その他32社わら選択 \\
\hline & 製造年月 & YYYY/MM \\
\hline & 柔統への導入年月 & YYYY/MM \\
\hline & 自動監視の有無 & 選択(デフォルトはディジタルが全部，アナログ静上が常時監視，電気機棫がなし) \\
\hline & 移設年月 & YYYY/MM(リレーが調査期間内に移設された場合，従来の電気所などのデータは保存される) \\
\hline & 糜止年月 & YYYY/MM(リレーが調查期閒内に廃止された場合) \\
\hline & 設備数 & 1 回線1端子ごとに 1 装置を原則 \\
\hline & 系列数 & 1 件にn系列記述の場合はnとしてカウント \\
\hline \multirow{14}{*}{$\begin{array}{l}\text { 故 } \\
\frac{\text { 障 }}{\overrightarrow{7}} \\
1 \\
\text { 夕 }\end{array}$} & 故障番号 & 11桁で部述 \\
\hline & 故障の発生年月日 & YMrYMM/DDで記述 \\
\hline & 経過年月 & 系統導入あるいは前回の故障発生日から算出 \\
\hline & 原因1 & ハード，ソフト，その他，不明から選択 \\
\hline & 原因2 & $\begin{array}{l}\text { 原因10内容に応じて選択。ハード故障(仕様不良，設計不良，製造不良，施工不良，部品不良，取扱不良，不明)， } \\
\text { ソフト故障(仕様不良，設計不良，製造不良，不明から，不明(不明，調查中)，その他(任様不良，取扱不良)から選択。 }\end{array}$ \\
\hline & 故障部位 & $\begin{array}{l}\text { 故障の原因がハード不良の場合，リレー単体，プリント基板，入力変換器，タイマー，電源装置，補助りレー， } \\
\text { タイマーリレー，切替開閉器，その他，限定できずから選択 }\end{array}$ \\
\hline & 故障部品 & 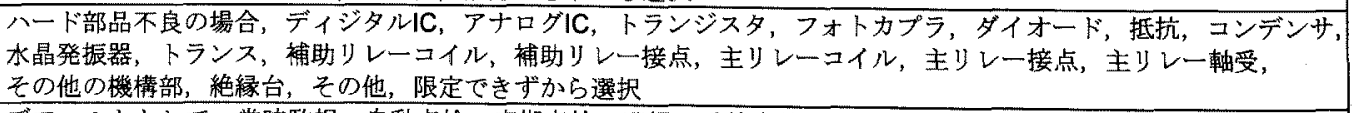 \\
\hline & 発見動機 & 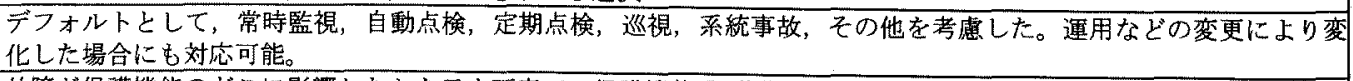 \\
\hline & 影響 & $\begin{array}{l}\text { 故障が保護機能のどこに影響したが示寸要素で，保護機能(誤動作側，不動作側，特性不良，不明)，常時監視機能， } \\
\text { 自動点検機能，その他の機能，不明，再開路能から選抧 }\end{array}$ \\
\hline & 故障の程度 & 故障が保護機能を阻害するか否かを判断する要素で，重故障，軽故障から選択 \\
\hline & 不良様相 & 永久故障，一過性故障加選択。 \\
\hline & 故障種別 & 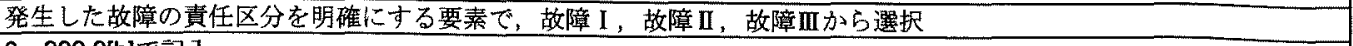 \\
\hline & 修復時閒 & 0〜999.9[h]で記入 \\
\hline & 状玩括よひ対参 & 全角256女字次为で記䞗 \\
\hline
\end{tabular}


などである。は，統計処理するデータのほとんどを選択式 とする(表 1 参照) ことで, 入力方法を容易とした。(2)は、表 2 に例示するように，該当機種のみを選択可能とするなどに より，裙入力在極力防止した。(3)では統計処理する項目に入 力がない場合にはメッセージを出し，入力を促している。(4) は設定条件に合致したデータのみを一覧として集める機能 を付加した。(5は表 1で”支店”と記載しているが, 各社が 独自の整理・分類を容易にするため，独自に定義する項目で， 以後は選択式データとして扱えるとともに，検索条件として も考慮できる。

表2 送電線保讙方式一筧

Tab. 2 Line Protection Systems Registered in RASPR

\begin{tabular}{|c|c|c|c|}
\hline 保護方式 & D & $s$ & $M$ \\
\hline 位相比較 & $x$ & 0 & $x$ \\
\hline 回線選抧 & 0 & 0 & 0 \\
\hline 過電流 & 0 & 0 & 0 \\
\hline 距離 & 0 & 0 & 0 \\
\hline FM電流差動 & $\bar{x}$ & $\mathrm{O}$ & $x$ \\
\hline PCM電流差動 & 0 & $x$ & $x$ \\
\hline 表示線 & 0 & 0 & 0 \\
\hline 方向比㜞 & 0 & 0 & 0 \\
\hline 位相比較+距離 & $x$ & 0 & $x$ \\
\hline 回線選択＋距雕 (1) & 0 & 0 & $x$ \\
\hline 回線選択+距離 (2) & 0 & $x$ & $x$ \\
\hline PCM電流差動+距離 & 0 & $x$ & $x$ \\
\hline 表示線十潞離 & 0 & 0 & $x$ \\
\hline
\end{tabular}

注)D，S，Mはそれぞれディジタル，アナログ静止，電気機珹型と機種を， また口は該当項目，メは該当しない入力できない項目を表す。

(3) 信頼度分析部の考え方保護りレーの信頼度を解析す る段階において，各種の集計をはじめ，いろいろな角度から 信頼度を解析することにより，効率的な保守運用計画の策定 などに寄与するデータの提供が必要となる。この部分につい ては以下を考虑して開発した。

(1) 各社固有の保守運用実態を反映した信賴度解析が可能

(2) 单年度ごとの倍頼度解析，年度間推移さらに遷移パラ メータの変化に対する信頼度への影響の解析を可能

(3) 集計については，操作の容易性を考虑しメニューから の選択力式を採用

\section{3. 任意の状態遭移図の構成手法}

まえがきでも触れたような，従来の信頼度解析における問 題点を以下に述へる方法で解決し，各社の保守運用実熊を反 映できる信顐度解析を可能とした。

\section{$<3.1>$ 状態嘾移図において考慮する保護リレーの状態}

状態遷移图は解析対象とする保護りレーが系統に導入さ れてから廃止されるまでの閒に湢かれるさまざまな状態一 の滞在摔を求める手法である。そこに現れる状態には，表3 に示す4種類がある。

$<3.2>$ 状態僄移図の構成手法

（1）基本ブロック 解析対象とする保護りレーに何らかの 原因で故障が発生する, 常時監視, 自動点検, 定期点检,
日常巡視，系統事故，その他のうちのいずれかの契機で発見 されると考える(故障発見契機の分類)。いま，定期点検を例 にとると，点倹周期がくると定期点検が行われ，もし故障が なければ，健全な状態で系統に再接続される。故障が発見さ れれば，原因の調査や故障部位の特定が行われ，適切に修理 された後，健全な状態となって系統に再接続される。

\section{表3 リレーの状媅}

Tab. 3 States in which a Relay Stays

\begin{tabular}{|c|c|}
\hline 健全 (A) & 故障がまったく存在しない状態 \\
\hline $\begin{array}{l}\text { 故陡中 } \\
\left(B_{y}\right)\end{array}$ & 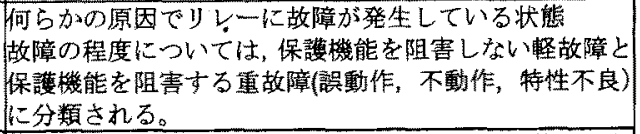 \\
\hline $\begin{array}{l}\text { 原因娚查 } \\
\text { 修理中 } \\
\left(R_{i}\right) \\
\end{array}$ & $\begin{array}{l}\text { 故障発見後，その原因や故障部位が調查され，修理が } \\
\text { われている状態。リレーは停止されている。修理完了後 } \\
\text { リレーは健全に戻る。 }\end{array}$ \\
\hline $\begin{array}{l}\text { 一時停止中 } \\
\text { (S) }\end{array}$ & $\begin{array}{l}\text { リレーは健全であるが，保守のために一時的にリレ } \\
\text { 系統から接続を除外される状態。終了後には䬱全に } \\
\text { る。 }\end{array}$ \\
\hline
\end{tabular}

注) B,R，Sに付随寸る添字 $i, j$ のち，i は故障発見契機に割り当てた

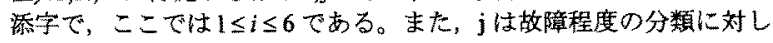

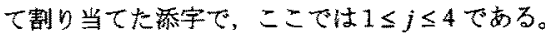

このように、リレーの状態間の遷移をみると

(1). 健全状態から一時停止状態（リレー装置が一时的に 系統から接続が解除され，保護機能を発揮しない状 態）一移行し，その保守が終了すると健全に戻る遷 移(ループI)

(2). 健全状熊から何らかの原因で故障が発生し，その原 因が調查され，修理の後に健全に復帰する僄移(ルー $フ ゚$ II)

という2つの遷移が一般に存在する。このとき，最大 $1 つ 0$ ループI と故障程度の段階区分から分類された数のループ IIからら構成される単位を基本ブロックと呼ぶ(図2)。

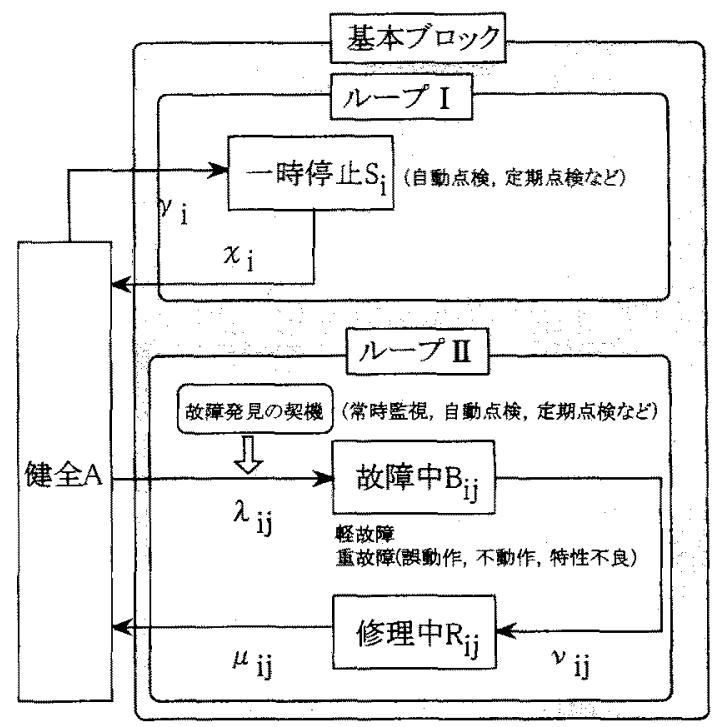

图 2 保謨リレーの状態の要移と基本ブロック Fig. 2 Transition Mode of a Protective Relay and "Fundamental Block" 
基本ブロックは故障発見契機ごとに分類され，これを組み 合わせることで任意の状態遷移図が作成される。これには, 基本ブロック間の状態の遷移がないことが前提となるが，こ れまで収集されたデータ(6)および今回収集したデータの分析 からこの遷移は無視できることを確認している。

なお, 各状態間の遷移は, 時間の逆数すなわち㭙間率で関 連付ける。このうち図2の入は故障率に対応する。

（2）状態遷䔟図の関係式考慮する状態遷移図が, 図 $20 \mathrm{k}$ 個の基本ブロックから構成されるとする。そして，1つの基 本ブロックは 1 つのループ I と $\mathbf{m}$ 個のループII から棈成さ れるとする。なお，ループIがない場合には $\gamma_{i}=0$ とする。

次に, 図3を参照し, また文献(4)の考え方を拡張して, 以 下の関係式が導かれる。まず，Aについて

$$
-\sum_{i=1}^{k} \gamma_{i} A+\sum_{i=1}^{k} \chi_{i} S_{i}-\sum_{i=1}^{k} \sum_{j=1}^{m} \lambda_{i j} A+\sum_{i=1}^{k} \sum_{j=1}^{m} \mu_{i j} R_{i j}=0
$$

その他の状態である $B_{i j}, R_{i j}, S_{i}$ については，それぞれ

$$
\begin{gathered}
\lambda_{i j} A-v_{i j} B_{i j}=0 \\
v_{i j} B i j-\mu_{i j} R_{i j}=0 \\
\gamma_{i} A-\chi_{i} S_{i}=0
\end{gathered}
$$

また，各状態の総和は1になるので，

$$
A+\sum_{j=1}^{k} \sum_{j=1}^{m} B_{i j}+\sum_{i=1}^{k} \sum_{j=1}^{m} R_{i j}+\sum_{i=1}^{k} S_{i}=1
$$

(2)(3)(4)式より $B_{i j}, R_{i j}$ および $S_{i}$ はすべてAで表せることに なる。すなわち

$$
\begin{aligned}
& B_{i j}=\frac{\lambda_{i j}}{v_{i j}} A \\
& R_{i j}=\frac{v_{i j}}{\mu_{i j}} B_{i j}=\frac{\lambda_{i j}}{\mu_{i j}} A \\
& S_{i}=\frac{\gamma_{i}}{\chi_{i}} A
\end{aligned}
$$

となるから，これらを(5)式に代入することにより，健全状熊 Aにある確率が(9)式のように求まる。(9)を(6) (8)に代入す ることにより，すべての状態に滞在する確率が求まることに なる。

$$
A=\frac{1}{1+\sum_{i=1}^{k} \sum_{j=1}^{m} \lambda_{i j}\left(\frac{1}{v_{i j}}+\frac{1}{\mu_{i j}}\right)+\sum_{i=1}^{k} \frac{\gamma_{i}}{\chi_{i}}}
$$

（3）本手法の特徽提案した状態遷移図構成手法による 信頼度解析の特徴を以下に述べる。

(1) 保護リレーの機種によらず同一の手法で信賴度を解 析できる。例えば自動監視機能を持たない電気機械型 ではそれに関する基本ブロックを消去することによ

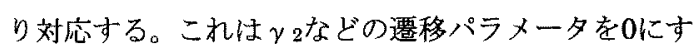
ることに対応する。

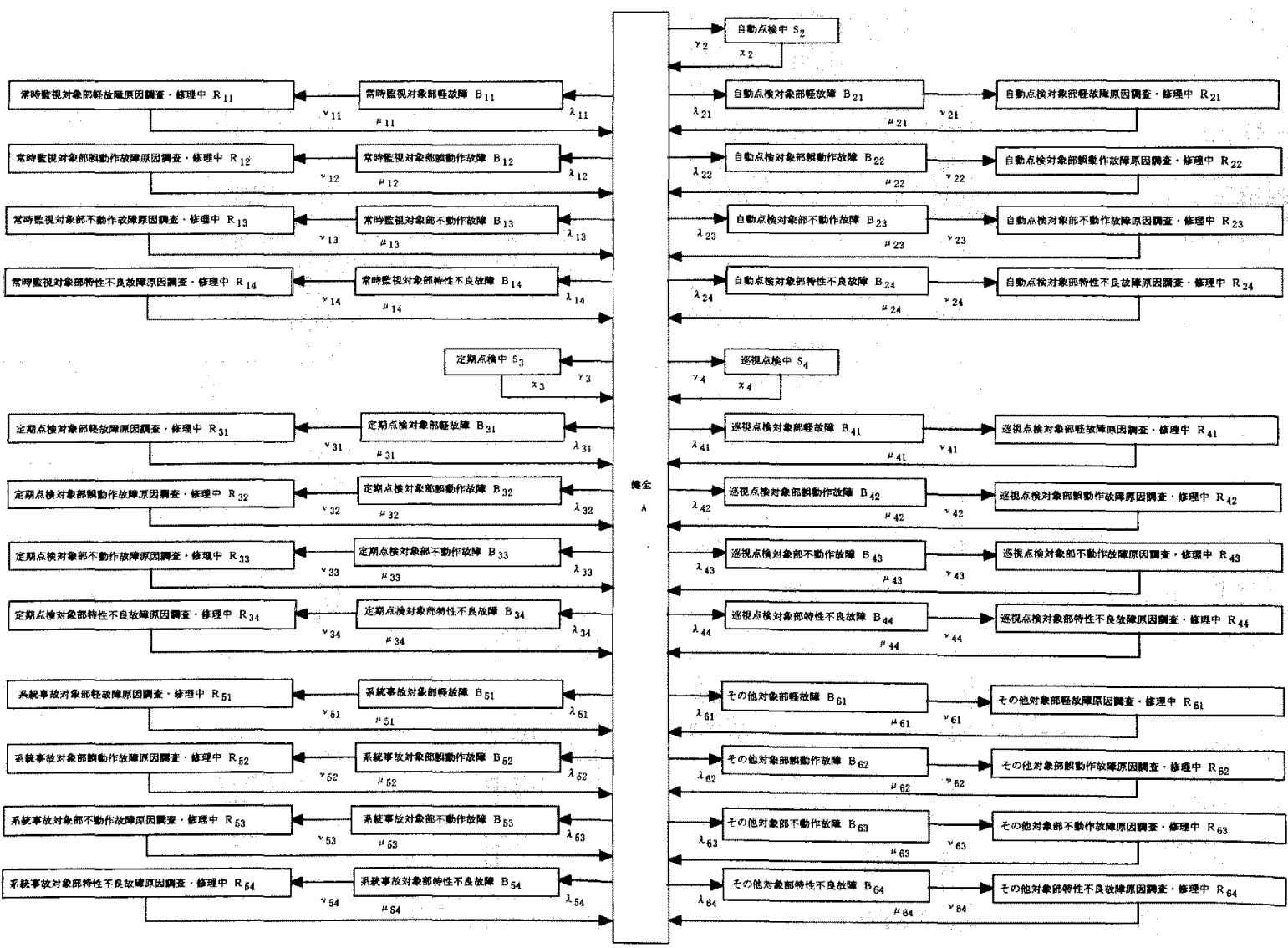

図 3 状態潓移図例

Fig. 3 An Example of Transition Diagram 
(2)保守運用の状況が变化した場合にも签易に対応可能 である。例えば，臨時点検などの状態が必要であれば， kを增やすことにより，プログラムの変更なしに状態 遷移図を容易に変更できる。

また，適用に際しての一般的な考え方は，次の通りである。

(1) 取り扱う故障は、リレー装置が系統に導入されてから 発生したものを対象とする。すなわち，工場での製造 過程など現地にて保護りレーが運用を開始以前に発 見された故障は対象外とした。

(2) 保護機能を阻害せず，そのまま保護りレ一を電力系統 に接続していても事故時には正しい忘動ができる軽 故障については，健全状態と同一に扱う。

(3) ディジタルリレーなどにおける自動点検（手動点検を 含む)中についてはトリップロックされ，一時的に系統 から接続を除外されるため，系統に接続される時間に は含めない。

(4) 信賴度指標 RASPRで解析する信頼度指標は, (10)(11)式で定義される稼動信頼度 $(\mathrm{RS})$, 動作信頼度 $(\mathrm{RO})^{(5)}$ (8)とした。ただし， $j=1$ は軽故障とした。

稼動信頼度 $R S$

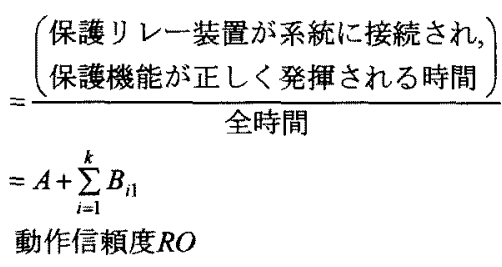

$=\frac{\left(\begin{array}{l}\text { 保護 } \\ \text { 保護機能が正しく装置が揮される統に接続され，間 }\end{array}\right)}{\text { 保護りレー䔒が置統に接続される時閒 }}$ $=\left(A+\sum_{i=1}^{k} B_{i 1}\right) /\left(A+\sum_{i=1}^{k} \sum_{j=2}^{m} B_{i j}\right)$

稼動信賴度は,リレーが采統に導入されてからの全時間を 対象に，保護リレーが健全で保護機能が正しく行われる状態 で系統に接続される時間率を表す。すなわち，なるべく短い 時間で効果的に保守を行い，保護機能を正しく発揮させるか を見る指標で，合理的かつ効果的な保守計画を行うための 1 つの指標となりうる。また, 動作信頼度は, 保護りレーが系 統に接続されている時閒を対象に, 保護機能が正しく発揮さ れる時間率を表したものである。すなわち，保謢機能を阻害 する重故障をいかに早く発見するかを考えるための指標の 1つとなりうる。

\section{4. 解析例}

ここでは，RASPRで収集したデータを基にした信頼度解 析について, 以下に例を示す。

<4.1> 基本ケースの信頼度 信頼度解析を行うためには, 解析対象とするリレーと対象年月を設定する。これにより， 故障件数と累積稼動時間が算出され，実績值である故障率が 求められる。次に, 図3に見られる各種遷移パラメータを定
める必要がある。この設定に際しては解析対象とするリレー の機種や保守運用寒態などをべースに定める。これをもとに 計算された信頼度を基本ケースの信賴度と呼ぶ。遷移パラメ 一タは，表4に示すように，時間を単位として与え内部で変 換した。なお，遷移パラメータを個別に直接設定することも できる。

表4 設定パラメータの例

Tab.4 An Example of Transition Parameters

\begin{tabular}{|c|c|c|c|}
\hline パラメータ & 表記 & 入力単位 & 設定値 \\
\hline 自動点検周期 & $\operatorname{tr} 2$ & day & 1 \\
\hline 自動点検所要時間 & $1 \times 2$ & $\mathrm{sec}$ & 200 \\
\hline 定期点検周期 & $1 \% 3$ & year & 6 \\
\hline 定期点検所要時間 & $1 x^{3}$ & hour & 8 \\
\hline 巡視周期 & $\mathrm{t} r 4$ & day & 1 \\
\hline 巡視点検所要時間 & $t \times 4$ & sec & 200 \\
\hline 保故障平均偖理所要時間 & $t \mu L$ & hour & 2 \\
\hline 重故障平均修理所要時間 & $\mathrm{t} \mu \mathrm{H}$ & hour & 6 \\
\hline $\begin{array}{l}\text { 常時監視対象部故障発見後リレー } \\
\text { が停止されるまでの平均時間 } \\
\end{array}$ & $\mathrm{t} \nu 1$ & $\sec$ & 10 \\
\hline $\begin{array}{l}\text { 自動点検対象部故障発見後りレ一 } \\
\text { が停止されるまでの平均時間 }\end{array}$ & 122 & day & $=1 \gamma 2 / 2$ \\
\hline $\begin{array}{l}\text { 定期点検対象部故障発見後りレー- } \\
\text { が停止されるまての平均時間 } \\
\end{array}$ & $\mathrm{t} \nu 3$ & year & $=\operatorname{tr} 3 / 2$ \\
\hline \begin{tabular}{|l|} 
巡視点㛟対象部故障発見後りレー- \\
が停止されるまでの平均時間 \\
\end{tabular} & $\mathrm{t} \nu 4$ & day & $=t r 4 / 2$ \\
\hline $\begin{array}{l}\text { 系統事故対象部故障発見後リレ- } \\
\text { が停止されるまでの平均時間 } \\
\end{array}$ & $\mathrm{t} \nu 5$ & year & 1 \\
\hline $\begin{array}{l}\text { その他対象部故障発見後リレーが } \\
\text { 停止されるまでの平均時間 }\end{array}$ & $\mathrm{t} \nu 6$ & year & 1 \\
\hline
\end{tabular}

注)パラメータ表記については圂3参照，また設定值はここでの 解析で使用した值

いま，解析対象として直接接地系のディジタル型送電線保 護(累積稼動時間 $2.29 \times 10^{8}$ )で解析した例を以下に示す。本計 算では, 遷移パラメータは表4の䛧を, 障害データは平成 9 年度 1 年分を使用した。故障率は全67件の故障から表5のよ うに算出された。このとき稼動信頼度RS，動作信頼度ROを 不信頼度で表すと

$$
\begin{aligned}
& 1-R S=8.82 \times 10^{-4} \\
& 1-R O=2.68 \times 10^{-4}
\end{aligned}
$$

であった。

表5 故障率(単位: $f i t=$ 件 $/ 10^{9}$ 時閒)

\begin{tabular}{|c|c|c|c|c|c|c|c|c|c|c|c|}
\hline \multicolumn{2}{|c|}{ 時監視 } & \multicolumn{2}{|c|}{ 自動点検 } & \multicolumn{2}{|c|}{ 定期点㭘 } & \multicolumn{2}{|c|}{ 巡視 } & \multicolumn{2}{|c|}{ 系統事故 } & \multicolumn{2}{|c|}{ 年の他 } \\
\hline 411 & 44 & $\lambda_{21}$ & 17 & $\lambda_{31}$ & 0 & $\lambda_{41}$ & 26 & $\lambda_{51}$ & 0 & $\lambda_{61}$ & \\
\hline & 37 & & & & & 4 & & & & $\begin{array}{c}6.62 \\
-2\end{array}$ & \\
\hline & 79 & & & $\lambda_{33}$ & & $n_{4}$ & & & & & \\
\hline & 3 & & & & & & & & & $\lambda_{64}$ & \\
\hline
\end{tabular}

Tab.5 Failure Rate of Digital Type Line Protection for Direct Ground System (in fit)

<4.2> 遷移パラメータの変化による信頼度指標への影響

直接接地系のディジタル型送電線保護を対象に, 定期点検 周期を 1 年 25 年まで変化させたとき, 基淮の 6 年での值に 比較して，信頼度指標八の影響を解析した結果を図4に示す。 障害データは前出の例と同㥞に平成 9 年度のデータを使用 Lた。 
これによれば, 稼動信頼度は, 定期点検周期の延伸ととも に，定期点検中への滞在確率が低下するため，一旦は向上す るが, 次第に定期点検対象部の重故障中への滞在確率が大き くなり，稼動信頼度は低下寸る。動作信頼度については，定 期点検周期の延伸とともに，定期点検対象部重故障中への滞 在確率が大きくなるため低下していくことがわかる。これか ら，保護機能を阻害する重故障を速やかに発見し，かつ定期 点検対象部の重故障を確実に発見できる自動監視手法の確 立が重要であると推察できる。

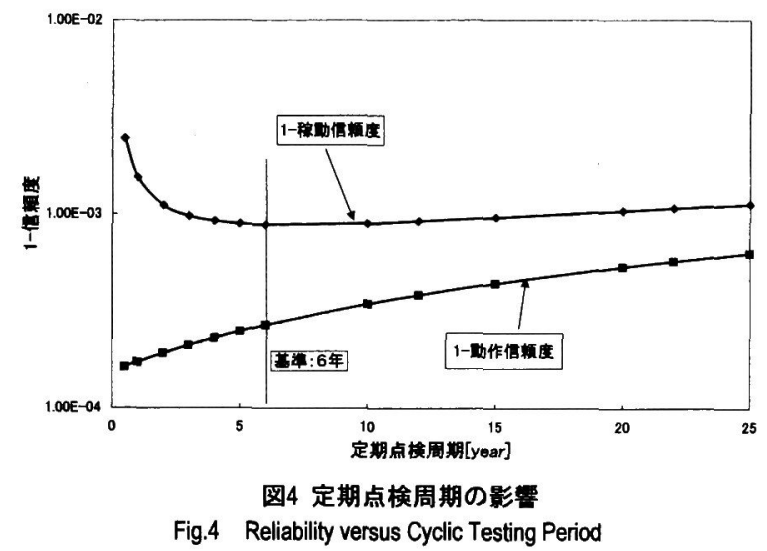

現在はまだ 2 ヶ年分のデータの蓄積であるが，これを蓄積 し，特に故障データの分析を詳細に行うことにより，適切な 自動監視範囲の提言，より合理的かつ効果的な保守運用計画 に資するデータの提供などが可能となると考える。

\section{5. おわりに}

本論文では，保護リレーの信頼度を多角的に解析可能かつ パソコン上で動作する系統保護リレ一信頼度解析システム (RASPR)について述べた。これを用いれば，リレー設備や故 障に関する各種集計のほか, 信頼度の推移, 遷移パラメータ の変化に対する信頼度指標への影響をも解析できるため, 効 果的な保守計画の立案などに役立てることができる。その中 心となる状態遷移図の作成に当たっては，保護リレーの保 守・運用形態が変化しても対応可能な状態遷移図の構成手法 を提案した。これにより,リレー機種によらず統一的に解析 できるとともに保守運用状況が変化してもプログラムの変 更なしに状態遷移図の作成が可能である。

RASPRの開発に当たっては, 電気事業連合会 電力技術部 の池田副部長, 今田副長, 電気事業連合会 保護制御担当課 長会議の下に設置されている保護設備検討会メンバーの 方々の多大な協力を賜った。さらに，本研究の遂行において は当所電力システム部の谷口部長, 熊野主任研究員, 侏電力 計算センターの坪井氏に多大なご指導・援助を賜った。ここ に紙面をお借りして深謝致します。

開発した系統保護リレー信頼度解析システムは全電力会 社に導入され，稼動している。

(平成12年6月7日受付)
参考文献

(1) 主幹系統保護施設専門委員会,「主幹系統保護施設」,電 気協同研究 第25巻第4号,昭和44年11月

（2）保護リレー自動監視専門委員会,「保護リレー自動監視」, 電気協同研究 第 28 巻第 1 号,昭和 47 年 7 月

（3）後備保護継電方式専門委員会,「後備保護継電方式」,電 気協同研究 第 37 巻第 1 号,昭和 56 年 6 月

（4）保護継電装置保守点検専門委員会, 「保護継電装置保守点 検方策」,電気協同研究 第39巻第1号,昭和58年6月

(5) デジタルリレー専門委員会,「デジタルリレー」,電気㙝 同研究 第41巻第4号,昭和61年1月

(6) 第二世代ディジタルリレー専門委員会, 「第二世代ディジ タルリレー」,電気協同研究 第50巻第 1 号,平成6年 4 月

(7) 坪井, 「電力系統保護りレーの信頼度解析手法」, 電力中 央研究所 研究報告 73108 昭和 49 年7月

(8) 坪井,亀田,「デジタルリレー信頼度解析手法の開発」, 電力中央研究所 研究報告 184041 昭和61年7月

(9) G. Dienne, "Reliability of protection and automation systems", electra, Mars-March, 1982, pp36-39

亀田秀之（正員）

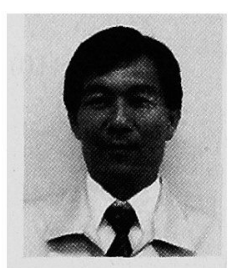

昭和 56 年 3 月成蹊大学大学院前期博士過程 電気工学専攻修了。同年4月(財)電力中央研 究所入所。平成8年 8 月 平成 9 年 8 月アメリ カ・テキサス大学アーリントン校客員研究 員。超電導機器を含む電力系統の保護・制 御, 超電導限流器に関する研究に従事。 2000年電気学会論文賞受賞。 